\title{
REDUKSI KEWENANGAN ATRIBUSI PEMERINTAH DAERAH DALAM PENGATURAN PEMILIHAN KEPALA DESA
}

\author{
Kajian Putusan Nomor 30 P/HUM/2016
}

\section{THE REDUCTION OF ADMINISTRATIVE GOVERNMENT'S ATRIBUTION AUTHORITY IN VILLAGE CHIEF ELECTION}

\author{
An Analysis of Court Decision Number 30 P/HUM/2016

\section{Proborini Hastuti} \\ Fakultas Hukum UPN Veteran Jawa Timur \\ Jl. Raya Rungkut Madya, Gunung Anyar, Surabaya 60294 \\ E-mail: proborini.hastuti@gmail.com
}

\begin{abstract}
Naskah diterima: 12 Oktober 2017; revisi: 17 November 2017; disetujui 27 Maret 2018
http://dx.doi.org/10.29123/jy.v11i1.265
\end{abstract}

\begin{abstract}
ABSTRAK
Pemerintah Daerah Kabupaten Demak membuat peraturan turunan dari ketentuan pencalonan pemilihan kepala desa di Pasal 33 Undang-Undang Nomor 6 Tahun 2014 tentang Desa ke dalam Pasal 24 ayat (1) Peraturan Daerah Kabupaten Demak Nomor 5 Tahun 2015 tentang Kepala Desa. Peraturan daerah tersebut berhenti berlaku setelah Mahkamah Agung melakukan hak uji materi dan menghasilkan Putusan Nomor 30 P/ HUM/2016 yang menyatakan peraturan daerah tersebut bertentangan dengan peraturan yang lebih tinggi sehingga tidak memiliki kekuatan hukum mengikat. Berdasarkan hal tersebut perlu dianalisis apakah Putusan Nomor 30 P/HUM/2016 memiliki dampak hukum terhadap kewenangan atribusi pemerintah daerah Kabupaten Demak berdasarkan UndangUndang Nomor 6 Tahun 2014 tentang Desa. Penelitian ini adalah penelitian hukum normatif yang dilakukan menggunakan penelitian kepustakaan. Hasil penelitian ini menunjukkan bahwa Putusan Mahkamah Agung tersebut memberikan implikasi terhadap adanya reduksi kewenangan atribusi yang dimiliki oleh pemerintah daerah dalam hal pemilihan kepala desa sebagai bagian
\end{abstract}

dari penyelenggara pemerintahan di Indonesia.

Kata kunci: kewenangan atribusi, pemilihan kepala desa, hak uji materi.

\section{ABSTRACT}

Demak Regency Administrative Government made a regulation derived from Village Chief Election Regulation in Article 33 of Law Number 6 of 2014 regarding Village and transformed into Article 24 paragraph (1) of Demak Regency Regulation Number 5 of 2015 regarding Village Chief. The regional regulation ceased to take effect after the Supreme Court conducted a judicial review and ruled Decision Number $30 \mathrm{P} /$ $H U M / 2016$ stating that the regional regulation is in conflict with higher level regulations and therefore has no binding legal force. Based on this, it is necessary to analyze whether the Supreme Court Decision Number $30 \mathrm{P} / \mathrm{HUM} / 2016$ has a legal effect on the attribution authority of the Administrative Government of Demak Regency pursuant to Law Number 6 of 2014 regarding Village. This analysis is a normative legal research conducted using literature research. The result of the 
analysis shows that the Supreme Court Decision has implication to the reduction of attribution authority of the regional government in village chief election as part of managing governance in Indonesia.

Keywords: attribution authority, village chief election, right to judicial review.

\section{PENDAHULUAN}

\section{A. Latar Belakang}

Era otonomi daerah di Indonesia saat ini, desa mempunyai kewenangan yang lebih luas dalam hal mengatur dan mengurus kepentingan masyarakat berdasarkan hak asal-usul, adat istiadat, dan nilai-nilai sosial budaya masyarakat dan melaksanakan bagian-bagian dari suatu urusan pemerintahan yang dilimpahkan oleh pemerintah kabupaten atau kota.

Kewenangan desa untuk mengatur dan mengurus urusan masyarakat secara mandiri mensyaratkan adanya manusia-manusia handal dan mumpuni sebagai pengelola desa sebagai self governing community (komunitas yang mengelola pemerintahannya secara mandiri). Kaderisasi desa menjadi kegiatan yang sangat strategis bagi terciptanya desa yang kuat, maju, mandiri, dan demokratis. Kaderisasi desa meliputi peningkatan kapasitas masyarakat desa di segala kehidupan, utamanya pengembangan kapasitas di dalam pengelolaan desa secara demokratis (Ghozali, 2015: 8-9). Jadi untuk keperluan pengurusan masyarakat tersebut tentunya dibutuhkan seorang pemimpin yang mampu memimpin jalannya pemerintahan desa.

Kepala desa mempunyai tugas menyelenggarakan urusan pemerintahan, pembangunan, dan kemasyarakatan, sehingga kepala desa adalah unsur penyelenggara pemerintahan desa yang dipilih langsung oleh penduduk desa sebagai pemimpin pemerintahan desa. Berdasarkan hal tersebut, pengaturan mengenai pemilihan kepala daerah yang sesuai dan tepat dalam suatu daerah menjadi sesuatu yang perlu diperhatikan, khususnya dalam hal pencalonan.

Pemilihan kepala desa termuat dalam Undang-Undang Nomor 6 Tahun 2014 tentang Desa, dalam Pasal 33 dicantumkan persyaratan untuk dapat dicalonkan sebagai kepala desa. Ketentuan tersebut secara eksplisit memberikan kewenangan atribusi kepada pemerintah daerah (dalam hal ini kabupaten/kota) untuk dapat menentukan syarat lain yang diatur dalam Peraturan Daerah (Pasal 33 huruf m).

Pemerintahan daerah dalam hal mengurus dan mengatur urusannya sendiri, pemerintahan daerah berhak untuk membuat peraturan daerah sesuai dengan kebutuhan, situasi, dan kondisi daerahnya. Peraturan daerah dapat berfungsi sebagai alat untuk memperlancar jalannya pemerintahan di daerah dan juga dapat memberi petunjuk terhadap hal-hal yang telah diatur dan dilaksanakan. Pemerintah daerah sebagai penyelenggara pemerintahan daerah tidak terlepas dari tugas untuk membina ketenteraman dan ketertiban masyarakat di daerahnya (Ayunita, 2014: 40).

Berkaitan dengan hal di atas, Pemerintah Daerah Kabupaten Demak membuat peraturan turunan dari ketentuan pencalonan di UndangUndang Desa tersebut ke dalam Pasal 24 ayat (1) Peraturan Daerah Kabupaten Demak Nomor 5 Tahun 2015 tentang Kepala Desa. Hal ini menjadi menarik untuk dikaji karena Mahkamah 
Agung dalam Putusan Nomor 30 P/HUM/2016 membatalkan ketentuan peraturan daerah tersebut.

Putusan Nomor 30 P/HUM/2016 berawal dari adanya pengajuan permohonan keberatan hak uji materi yang ditujukan pada perda tersebut. Adapun hak uji materi yang dimiliki Mahkamah Agung merupakan wewenang untuk menilai, apakah suatu produk legislatif seperti peraturan daerah misalnya terjelma melalui caracara (procedure) sebagaimana telah ditentukan atau diatur dalam peraturan perundang-undangan yang berlaku atau tidak (Nasihuddin, 2013: 431). Norma yang terdapat dalam Peraturan Daerah Kabupaten Demak Nomor 5 Tahun 2015 yang dilakukanuji materi karena dianggap bertentangan dengan peraturan yang lebih tinggi dan dianggap mencederai hak konstitusonal masyarakat yaitu Pasal 24 ayat (1) huruf o dan Pasal 106 ayat (2). Adapun pertimbangan Mahkamah Agung dalam memutus perkara tersebut menyatakan:

Bahwa Pasal 24 ayat (1) huruf o dan Pasal 106 ayat (2) Peraturan Daerah Kabupaten Demak Nomor 5 Tahun 2015 pada pokoknya mengatur syarat pencalonan kembali sebagai kepala desa dikaitkan dengan lamanya menjabat berdasarkan hitungan waktu, sedangkan Pasal 33 huruf 1, Pasal 39 ayat (2) Undang-Undang Nomor 6 Tahun 2014 dan Pasal 47 ayat (2) Peraturan Pemerintah Nomor 43 Tahun 2014 mengatur syarat pencalonan kembali dikaitkan dengan lamanya menjabat berdasarkan periodesasi;

Bahwa pengaturan dalam objek permohonan merupakan norma baru yang berbeda dengan maksud dari norma yang telah diatur dalam peraturan perundangundangan yang lebih tinggi, sehingga mempunyai konsekuensi hukum yang berbeda dari peraturan dasarnya tersebut;

Bahwa berdasarkan pertimbanganpertimbangan tersebut di atas, terbukti bahwa materi muatan Pasal 24 ayat (1) huruf o dan Pasal 106 ayat (2) Peraturan
Daerah Kabupaten Demak Nomor 5 Tahun 2015 tentang Kepala Desa (Lembaran Daerah Kabupaten Demak Tahun 2015 Nomor 5, Tambahan Lembaran Daerah Kabupaten Demak Nomor 5) bertentangan dengan peraturan perundang-undangan yang lebih tinggi yaitu:

- $\quad$ Pasal 33 huruf 1, Pasal 39 ayat (2) Undang-Undang Nomor 6 Tahun 2014 tentang Desa (Lembaran Negara RI Tahun 2014 Nomor 7, Tambahan Lembaran Negara RI Nomor 5495);

- Pasal 47 ayat (2) Peraturan Pemerintah Nomor 43 Tahun 2014 tentang Peraturan Pelaksanaan Undang-Undang Nomor 6 Tahun 2014 tentang Desa (Lembaran Negara RI Tahun 2014 Nomor 123, Tambahan Lembaran Negara RI Nomor 5539).

Pertimbangan hakim di atas terlihat bahwa hakim hanya menitikberatkan pada apakah norma dalam perda a quo bertentangan dengan norma asli dalam undang-undang di atasnya dan menyimpulkan terjadi pertentangan lex superior derogate legi posterior tanpa melakukan interpretasi lanjutan dan menilai dari indikatorindikator lain yang menjadi dasar peraturan daerah tersebut terbentuk. Hal ini tentunya menjadi problem ketika seharusnya sebuah putusan judicial review dalam pertimbangannya hakim dituntut untuk menelaah secara komprehensif.

Akhirnya, Mahkamah Agung menyatakan bahwa perda a quo tidak mempunyai kekuatan hukum mengikat. Pasal 24 ayat (1) huruf o dan Pasal 106 ayat (2) Peraturan Daerah Kabupaten Demak Nomor 5 Tahun 2015 yang pada pokoknya mengatur syarat pencalonan kembali sebagai kepala desa dikaitkan dengan lamanya menjabat berdasarkan hitungan waktu, sedangkan Pasal 33 huruf 1, Pasal 39 ayat (2) 
Undang-Undang Nomor 6 Tahun 2014 dan Pasal 47 ayat (2) Peraturan Pemerintah Nomor 43 Tahun 2014 mengatur syarat pencalonan kembali dikaitkan dengan lamanya menjabat berdasarkan periodesasi, sehingga dianggap pengaturan dalam objek permohonan merupakan norma baru yang berbeda dengan maksud dari norma yang telah diatur dalam peraturan perundangundangan yang lebih tinggi.

Menarik untuk dikaji mengenai putusan judicial review tersebut jika dikaitkan dengan kewenangan atribusi yang diberikan oleh undang-undang (Pasal 33 huruf m UndangUndang Desa) terhadap suatu pemerintahan daerah khususnya dalam hal-hal yang mengatur pemilihan kepala desa dalam suatu desa yang berada dalam lingkup suatu kabupaten/kota.

\section{B. Rumusan Masalah}

Berdasarkan latar belakang di atas, maka permasalahan yang diangkat dalam penelitian ini adalah apakah Putusan Nomor 30 P/HUM/2016 memiliki dampak hukum terhadap kewenangan atribusi Pemerintah Daerah Kabupaten Demak berdasarkan Undang-Undang Nomor 6 Tahun 2014 tentang Desa?

\section{Tujuan dan Kegunaan}

Tujuan dari tulisan ini adalah untuk mengetahui, memahami, menelaah, dan menganalisis apakah Putusan Nomor $30 \mathrm{P} /$ HUM/2016 memiliki dampak hukum terhadap kewenangan atribusi Pemerintah Daerah Kabupaten Demak berdasarkan Undang-Undang Nomor 6 Tahun 2014 tentang Desa sebagai bagian dari penyelenggara pemerintahan di Indonesia.
Adapun manfaat dari tulisan ini adalah sebagai berikut:

1. Bagi pengembangan ilmu pengetahuan, tulisan ini diharapkan dapat memberikan manfaat bagi pengembangan ilmu pengetahuan hukum, khususnya dalam bidang kenegaraan, terutama mengenai hal-hal yang berkaitan dengan implikasi Putusan Nomor 30 P/HUM/2016 terhadap kewenangan yang dimiliki pemerintah daerah. Sehingga tulisan ini dapat digunakan untuk memperkaya khazanah ilmu pengetahuan, menambah dan melengkapi perbendaharaan dan koleksi karya ilmiah serta memberikan kontribusi pemikiran yang menyoroti dan membahas konsep pembagian kewenangan di Indonesia; dan

2. Bagi praktik kenegaraan, tulisan ini diharapkan akan memberikan manfaat untuk melahirkan putusan-putusan yang ideal dan dapat memberikan rasa keadilan kepada masyarakat.

\section{Tinjauan Pustaka \\ 1. Kewenangan Atribusi}

Kata kewenangan berasal dari kata dasar wenang yang diartikan sebagai hal berwenang, hak dan kekuasaaan yang dipunyai untuk melakukan sesuatu. Kewenangan adalah apa yang disebut kekuasaan formal, kekuasaan yang berasal dari kekuasaan legislatif (diberi oleh undang-undang) atau dari kekuasaan eksekutif administratif. Kewenangan yang biasanya terdiri dari beberapa wewenang adalah kekuasaan terhadap segolongan orang tertentu atau kekuasaan terhadap suatu bidang pemerintahan (Atmosudirjo, 2006: 78). 
Secara konseptual harus dibedakan antara kewenangan (authority, gezag) dengan wewenang (competence, bevoegheid) (Hakim, 2011: 115). Kewenangan adalah apa yang disebut kekuasaan formal, kekuasaan yang berasal dari kekuasaan yang diberikan oleh undang-undang, sedangkan wewenang hanya mengenai suatu "onderdeel" (bagian) tertentu saja dari kewenangan. Di dalam kewenangan terdapat wewenang-wewenang (rechtsbe voegdheden).

Wewenang merupakan lingkup tindakan hukum publik, lingkup wewenang pemerintahan, tidak hanya meliputi wewenang membuat keputusan pemerintah (bestuur), tetapi meliputi wewenang dalam rangka pelaksanaan tugas dan memberikan wewenang serta distribusi wewenang utamanya ditetapkan dalam peraturan perundang-undangan. Pengertian wewenang menurut Stout adalah:

\section{"Bevoegheid wet kan worden omscrevenals het geheel van bestuurechttelijke bevoegdheden door publiekrechtelijke rechtssubjecten in het bestuurechttelijke rechtsverkeer." (Wewenang dapat dijelaskan sebagai keseluruhan aturan- aturan yang berkenaan dengan perolehan dan penggunaan wewenang pemerintah oleh subjek hukum publik dalam hukum publik) (Stout, 2004: 4).}

Kewenangan yang dimiliki oleh organ (institusi) pemerintahan dalam melakukan perbuatan nyata (riil), mengadakan pengaturan atau mengeluarkan keputusan selalu dilandasi oleh kewenangan yang diperoleh dari konstitusi secara atribusi, delegasi, maupun mandat. Suatu atribusi menunjuk pada kewenangan yang asli atas dasar konstitusi (UUD NRI 1945). Pada kewenangan delegasi, harus ditegaskan suatu pelimpahan wewenang kepada organ pemerintahan yang lain. Pada mandat tidak terjadi pelimpahan apapun dalam arti pemberian wewenang, akan tetapi yang diberi mandat bertindak atas nama pemberi mandat. Dalam hal ini kewenangan adalah merupakan hak menggunakan wewenang yang dimiliki seorang pejabat atau institusi menurut ketentuan yang berlaku (Ridwan, 2013: 99).

Menurut KBBI, kata wewenang disamakan dengan kata kewenangan yang diartikan sebagai hak dan kekuasaan untuk bertindak, kekuasaan membuat keputusan, memerintah dan melimpahkan tanggung jawab kepada orang atau badan lain (Hidjaz, 2010: 35).

Brouwer berpendapat bahwa atribusi merupakan kewenangan yang diberikan kepada suatu organ (institusi) pemerintahan atau lembaga negaraoleh suatubadanlegislatifyangindependen. Kewenangan ini adalah asli, yang tidak diambil dari kewenangan yang ada sebelumnya. Badan legislatif menciptakan kewenangan mandiri dan bukan perluasan kewenangan sebelumnya dan memberikan kepada organ yang berkompeten (Brouwer \& Schilder, 1998: 16-17).

Kewenangan harus dilandasi oleh ketentuan hukum yang ada (konstitusi), sehingga kewenangan tersebut merupakan kewenangan yang sah. Dengan demikian, pejabat (organ) dalam mengeluarkan keputusan didukung oleh sumber kewenangan tersebut. Stroink menjelaskan bahwa sumber kewenangan dapat diperoleh bagi pejabat atau organ (institusi) pemerintahan dengan cara atribusi, delegasi dan mandat. Adapun kewenangan tersebut juga dapat diaplikasikan melalui pembentukan peraturan daerah.

Peraturan daerah (perda) adalah bentuk peraturan perundang-undangan di bawah undang-undang dan perpu, peraturan pemerintah, dan peraturan presiden, akan tetapi dari segi isinya maupun mekanisme pembentukannya, 
Perda mempunyai kemiripan dengan undangundang (Asshiddiqqie, 2006: 93). Fungsi perda kabupaten/kota adalah untuk menyelenggarakan otonomi daerah sepenuhnya di tingkat kabupaten/ kota dan tugas pembantuan (medebewind) dalam rangka mengurus kepentingan rakyat setempat menurut prakarsa sendiri berdasarkan aspirasi dan keadaan sosial masyarakat, termasuk salah satunya ikut serta dalam merumuskan syarat lain dalam pencalonan kepala desa menurut keadaan sosial di daerahnya seperti halnya dalam Peraturan Daerah Kabupaten Demak Nomor 5 Tahun 2015 tentang Kepala Desa.

\section{Pemilihan Kepala Desa}

Hukum pemerintahan daerah sangat erat kaitannya atau salah satu hal yang dibicarakan adalah desa. Van Vollenhoven (dikutip dalam Taufiq, 2011: 1-2) mengatakan dalam kalimat awal bukunya yang berjudul Staatsrecht Oversee bahwa pada tahun 1596 ketika kapal berbendera Belanda pertama yang memasuki perairan kepulauan Indonesia, wilayah ini secara hukum ketatanegaraan bukanlah wilayah yang liar dan kosong. Di sana terdapat setumpuk lembagalembaga pengaturan dan kewibawaan melalui pemerintahan oleh atau terhadap suku-suku, desadesa, persatuan-persatuan desa, republik-republik atau kerajaan kerajaan. Van Vollenhoven juga menegaskan, ketatanegaraan tersebut bersifat pribumi (inheemsch geleven) meski pengaruh Hindu dan Islam pada kehidupan rakyat tetap berlangsung.

Masyarakat sudah meningkatkan diri dengan membentuk perkampungan-perkampungan yang tetap. Tradisi dari zaman ini telah menentukan bentuk dan susunan percandian kita. Menurut Soepomo (Hutagalung, 2005: 6), sifat ketatanegaraan Indonesia yang masih asli, yang sampai sekarang dapat terlihat dalam kehidupan sehari-hari ialah ketatanegaraan desa, baik di Jawa, Sumatera, maupun kepulauan Indonesia lainnya.

Menurut Attamimi, dengan demikian maka hakikat Negara Indonesia ialah desa yang sangat besar dengan unsur-unsur wawasan modern (Huda, 2017: 12). Maka dari itu Negara Republik Indonesia dalam sistem pemerintahannya memasukkan pemerintahan desa sebagai wujud otonomi desa agar mempunyai wewenang untuk mengurus rumah tangganya sendiri termasuk dalam bidang pemerintahan desa, yang tertuang dalam Undang-Undang Nomor 6 Tahun 2014 tentang Desa. Dalam mewujudkan pemerintahan desa diperlukan seorang pemimpin yang kepala desa, di mana tugasnya adalah menjalankan roda pemerintahan desa yang dipimpinnya. Dalam menentukan siapakah yang berhak menjadi kepala desa telah tertuang dalam undang-undang a quo dengan cara pemilihan kepala desa.

Pemilihan kepala desa adalah jalan untuk mewujudkan kedaulatan rakyat yang merupakan kesempatan bagi masyarakat desa untuk memilih kepala desa dan memutuskan apakah yang mereka inginkan untuk dijalankan oleh pemerintahan desa tersebut. Pemilihan kepala desa diharapkan sebagai proses demokratisasi di desa yang akan menjadi prasyarat bagi tumbuh kembangnya demokrasi di tingkat daerah maupun nasional.

Kepala desa memiliki hak wewenang dan tanggung jawab dalam pemerintahan desa, berupa menyelenggarakan rumah tangganya sendiri yang merupakan penyelenggara dan penanggung jawab utama dalam bidang pemerintahan, pembangunan, dan kemasyarakatan (Saiful, 2014: 3). Di samping itu kepala desa juga mengemban tugas 
membangun mental masyarakat desa baik dalam bentuk menumbuhkan maupun mengembangkan semangat membangun yang dijiwai oleh asas usaha bersama dan kekeluargaan. Berdasarkan hal tersebut dapat diketahui bahwa kepala desa mempunyai peran dan juga kedudukan yang sangat penting dalam pemerintahan desa. Kepala desa merupakan pemimpin terhadap jalannya tata urusan pemerintahan desa dan penyelenggara serta penanggung jawab atas jalannya roda pemerintahan dan pembangunan di dalam wilayahnya (Hariyati, 2015: 1922).

Pemilihan kepala desa bertujuan untuk memilih calon kepala desa yang bersaing dalam pemilihan kepala desa untuk dapat memimpin desa. Pemilihan kepala desa dilakukan secara langsung oleh masyarakat desa yang terdaftar dengan memilih langsung calon kepala desa yang dianggap oleh masyarakat mampu membawa aspirasi masyarakat dan pembangunan desanya (Janwandri, 2013: 239-240).

Demokrasi dalam konteks pemilihan kepala desa dapat dipahami sebagai pengakuan keanekaragaman serta sikap politik partisipasif dari masyarakat dalam bingkai demokratisasi pada tingkat desa. Hal ini merujuk pada Undang-Undang Nomor 6 Tahun 2014 yang mengakui penyelenggaraan pemerintahan desa sebagai subsistem dari sistem penyelenggaraan pemerintahan di mana desa berhak dan memiliki kewenangan untuk mengurus rumah tangga desa.

Perwujudan dari partisipasi dan peran aktif masyarakat merupakan dampak dari konsep demokrasi yang dianut di Indonesia. Negara demokrasi adalah negara yang diselenggarakan berdasarkan kehendak dan kemauan rakyat, atau jika ditinjau dari sudut organisasi ia (demokrasi) berarti pengorganisasian negara yang dilakukan oleh rakyat sendiri atau atas persetujuan rakyat karena kedaulatan berada di tangan rakyat (Mahfud, 2003: 19).

Salahsatubentuk daripartisipasimasyarakat dalam suatu negara tersebut menurut Samidjo (Rikardo, 2016: 2) adalah keterlibatannya dalam pemilihan umum (pemilu). Pemilu merupakan salah satu ciri dari pemerintahan yang demokratis. Termasuk di dalamnya adalah pemilihan kepala desa. Secara historis pemilihan kepala desa telah berjalan lama dan bersifat langsung umum, bebas, rahasia, jujur, dan adil telah dipahami sebagai pengakuan terhadap keanekaragaman sikap politik partisipasi masyarakat dalam demokratisasi di tingkat desa.

\section{Hak Uji Materi}

Sebelum adanya perubahan UUD NRI 1945, kewenangan judicial review ada pada Mahkamah Agung tetapi dibatasi hanya pada peraturan perundang-undangan di bawah undang-undang. Setelah adanya perubahan UUD NRI 1945, muncul lembaga baru yang bernama Mahkamah Konstitusi yang berwenang melakukan judicial review pada undang-undang terhadap undang-undang dasar, sedangkan Mahkamah Agung tetap pada kewenangan semula (Huda, 2008: 114).

Perubahan UUD NRI 1945 Pasal 24A ayat (1) menegaskan: "Mahkamah Agung berwenang mengadili pada tingkat kasasi, menguji peraturan perundang-undangan di bawah undang-undang, dan mempunyai wewenang lainnya yang diberikan oleh undang-undang." Selama ini, ketentuan wewenang Mahkamah Agung diatur dalam Undang-Undang Nomor 5 Tahun 2004 tentang Perubahan Atas Undang-Undang Nomor 14 Tahun 1985 tentang Mahkamah Agung. 
Mahkamah Agung memiliki kewenangan untuk melakukan pengujian peraturan perundangundangan terhadap undang-undang yang ditegaskan dalam Pasal 24A ayat (1) UUD NRI 1945. Pada level undang-undang, Mahkamah Agung juga ditegaskan kewenangannya dalam Undang-Undang Nomor 4 Tahun 2004 tentang Kekuasaan Kehakiman dan Undang-Undang Nomor 5 Tahun 2004 tentang Perubahan Atas Undang-Undang Nomor 14 Tahun 1985 tentang Mahkamah Agung. Kewenangan Mahkamah Agung untuk melakukan uji materi terhadap peraturan perundang-undangan di bawah undangundang, dalam hal ini termasuk perda.

Perundang-undangan mempunyai pengertian secara teoritik sebagai proses pembentukan peraturan perundang-undangan atau proses membentuk peraturan-peraturan negara, baik di tingkat pusat maupun di tingkat daerah (Febriansyah, 2016: 226). Produk hukum yang populis dan menjaga konstitusionalitas dalam penyelenggaraan ketatanegaraan dalam perwujudannya diperlukan adanya penegakan hukum. Salah satu cara penegakan hukum dan peraturan perundang-undangan adalah dengan pengujian terhadap peraturan perundangundangan yang dilakukan oleh lembaga peradilan (judicial review) (Maryadi, 2010: 103).

Pengaturan judicial review oleh Mahkamah Agung selanjutnya diatur dalam Undang-Undang Nomor 4 Tahun 2004 tentang Kekuasaan Kehakiman, Pasal 11 ayat (2) huruf b dan ayat (3) yang menegaskan, Mahkamah Agung mempunyai kewenangan menguji peraturan perundang-undangan di bawah undang-undang terhadap undang-undang.

Pernyataan tidak berlaku peraturan perundang-undangan sebagai hasil pengujian, dapat diambil baik dalam pemeriksaan tingkat kasasi maupun berdasarkan permohonan langsung kepada Mahkamah Agung. Kemudian kewenangan Mahkamah Agung tersebut juga diatur dalam Pasal 31 Undang-Undang Nomor 14 Tahun 1985 yang diubah dengan UndangUndang Nomor 5 Tahun 2004 tentang Mahkamah Agung, menyatakan Mahkamah Agung mempunyai wewenang menguji secara materiil hanya terhadap peraturan perundang-undangan di bawah undang-undang.

Melalui Undang-Undang Nomor 5 Tahun 2004, ketentuan mengenai wewenang pengujian peraturan perundang-undangan ditambah satu pasal yakni Pasal 31A ayat (1) yang menyatakan bahwa permohonan pengujian peraturan perundang-undangan di bawah undang-undang terhadap undang-undang diajukan langsung oleh pemohon atau kuasanya kepada Mahkamah Agung, dan dibuat secara tertulis dalam bahasa Indonesia. Ketentuan lebih lanjut mengenai pengujian peraturan perundang-undangan di bawah undang-undang diatur oleh Mahkamah Agung. Maka hukum acara pelaksanaan hak uji materi pun disesuaikan dengan perubahan tersebut, yang kemudian diatur dalam PERMA Nomor 1 Tahun 2011.

Pengajuan hak uji materi ke Mahkamah Agung menurut PERMA Nomor 1 Tahun 2011 dapat dilakukan melalui dua jalur, yakni gugatan dan permohonan keberatan. Di dalam PERMA Nomor 1 Tahun 2011, pengajuan hak uji materi ke Mahkamah Agung hanya dilakukan melalui permohonan keberatan. Perihal yang menjadi dasar permohonan pihak yang merasa dirugikan atas berlakunya suatu perda, telah ditegaskan dalam Pasal 31A ayat (3) hurufb Undang-Undang Nomor 3 Tahun 2009, bahwa uraian mengenai perihal yang menjadi dasar permohonan dan 
menguraikan dengan jelas bahwa:

a. Materi muatan ayat, pasal, dan/atau bagian peraturan perundang-undangan di bawah undang-undang dianggap bertentangan dengan peraturan perundang-undangan yang lebih tinggi; dan/atau

b. Pembentukan peraturan perundangundangan tidak memenuhi ketentuan yang berlaku.

Bagian pertama dikenal dengan istilah pengujian materiil, sedangkan pada bagian kedua, dikenal dengan istilah pengujian formal. Dari sini, timbul lagi permasalahan, yaitu pada bagian pertama yang apabila dikaitkan dengan pengujian perda, maka landasan bagi Mahkamah Agung untuk menguji perda terhadap undangundang, adalah materi muatan ayat, pasal, dan/atau bagian isi dari peraturan daerah. Selanjutnya, pada Pasal 31 ayat (2) UndangUndang Nomor 5 Tahun 2004 menjelaskan bahwa: "Mahkamah Agung menyatakan tidak sah peraturan perundang-undangan di bawah undang-undang atas alasan bertentangan dengan peraturan perundang-undangan yang lebih tinggi atau pembentukannya tidak memenuhi ketentuan yang berlaku."

Berdasarkan hal ini, apabila suatu peraturan daerah dipandang bahwa materi muatan ayat, pasal, dan/atau bagian perda bertentangan dengan undang-undang, maka sesuai dengan ketentuan Pasal 31 ayat (2) tersebut, Mahkamah Agung menyatakan bahwa perda tersebut tidak sah dan tidak mempunyai kekuatan hukum mengikat sesuai dengan ketentuan ayat (4). Bagaimana jika dalam proses pengujiannya, Mahkamah Agung hanya menemukan satu ayat, atau satu pasal, atau satu bagian dalam peraturan daerah tersebut yang bertentangan dengan peraturan perundang-undangan yang lebih tinggi (Zamroni, 2013: 267).

\section{METODE}

Tulisan ini adalah penelitian hukum normatif yang dilakukan menggunakan penelitian kepustakaan. Penelitian kepustakaan dilakukan untuk mendapatkan data sekunder dengan bahan atau materi berupa buku-buku, artikel-artikel, hasil-hasil penelitian, dan peraturan perundangundangan, serta pendapat ahli yang berkaitan dengan kewenangan atributif pemerintah daerah dalam rangka pengaturan pemilihan kepala desa.

Tulisan ini mengkaji dan menganalisis peraturan perundang-undangan atau bahan hukum lain yang berkaitan dengan Putusan Nomor 30 P/HUM/2016 dan keterkaitan lainnya dengan kewenangan pemerintahan daerah. Tulisan hukum ini dilakukan melalui pendekatan peraturan perundang-undangan (statutory approach), pendekatan kasus (case approach), dan pendekatan konseptual (conceptual approach) (Marzuki, 2007: 93-95).

Tulisan ini menggunakan jenis data sekunder yang difokuskan pada: a) bahan hukum primer, berupa peraturan perundang-undangan dan produk hukum yang terkait dengan tema penelitian; dan b) bahan hukum sekunder, berupa buku referensi dan jurnal yang terkait dengan tema penelitian dan menguraikan lebih lanjut bahan hukum primer dalam konteks dikotomi teoritik dan implementasi.

Tulisaninimenggunakanjenis data sekunder atau menggunakan metode pengumpulan data melalui studi pustaka (library research), sehingga metode pengumpulan data dilaksanakan dengan mencari pustaka yang relevan, baik bahan hukum 
primer maupun sekunder melalui perpustakaan maupun penelusuran database jurnal. Langkah yang lebih dahulu dilakukan yaitu menganalisis kewenangan atributif dalam tataran konsep dan praktik pemilihan kepala desa dalam peraturan kemudian dikaitkan dengan hak uji materi oleh Mahkamah Agung. Selanjutnya dianalisis lebih lanjut implikasi Putusan Nomor 30 P/HUM/2017 terhadap adanya reduksi kewenangan atributif pemerintah daerah dalam pengaturan pemilihan kepala desa, sehingga dapat berkontribusi positif pada optimalisasi kewenangan pemerintah daerah dan juga evaluasi terhadap upaya penguatan kualitas putusan hak uji materi Mahkamah Agung.

Penelitian hukum normatif, data yang terkait dengan reduksi kewenangan pemerintah daerah dalam pemilihan kepala desa (analisis putusan Mahkamah Agung a quo) kemudian dianalisis secara deskriptif kualitatif, yaitu dengan melakukan analisis yang pada dasarnya dikembalikan kepada tiga aspek, yaitu mengklasifikasi, membandingkan, dan menghubungkan. Berdasarkan hal tersebut maka penelitian yang dilakukan tidak semata-mata mengungkapkan kebenaran belaka, akan tetapi untuk memahami kebenaran tersebut. Terhadap data-data yang telah terkumpul dari penelitian kepustakaan selanjutnya akan dianalisis secara kualitatif untuk menjawab permasalahan yang diajukan.

\section{HASIL DAN PEMBAHASAN}

Problematika atas munculnya Putusan Nomor 30 P/HUM/2016 diindikasikan adanya pemahaman yang salah atas pemaknaan ketentuan dalam Undang-Undang Nomor 6 Tahun 2014 tentang Desa, yang secara implisit mengandung pemberian kewenangan atribusi kepada pemerintah daerah. Adapun pernyataan tersebut dapat dikonstruksikan dalam alur berpikir di bawah ini:

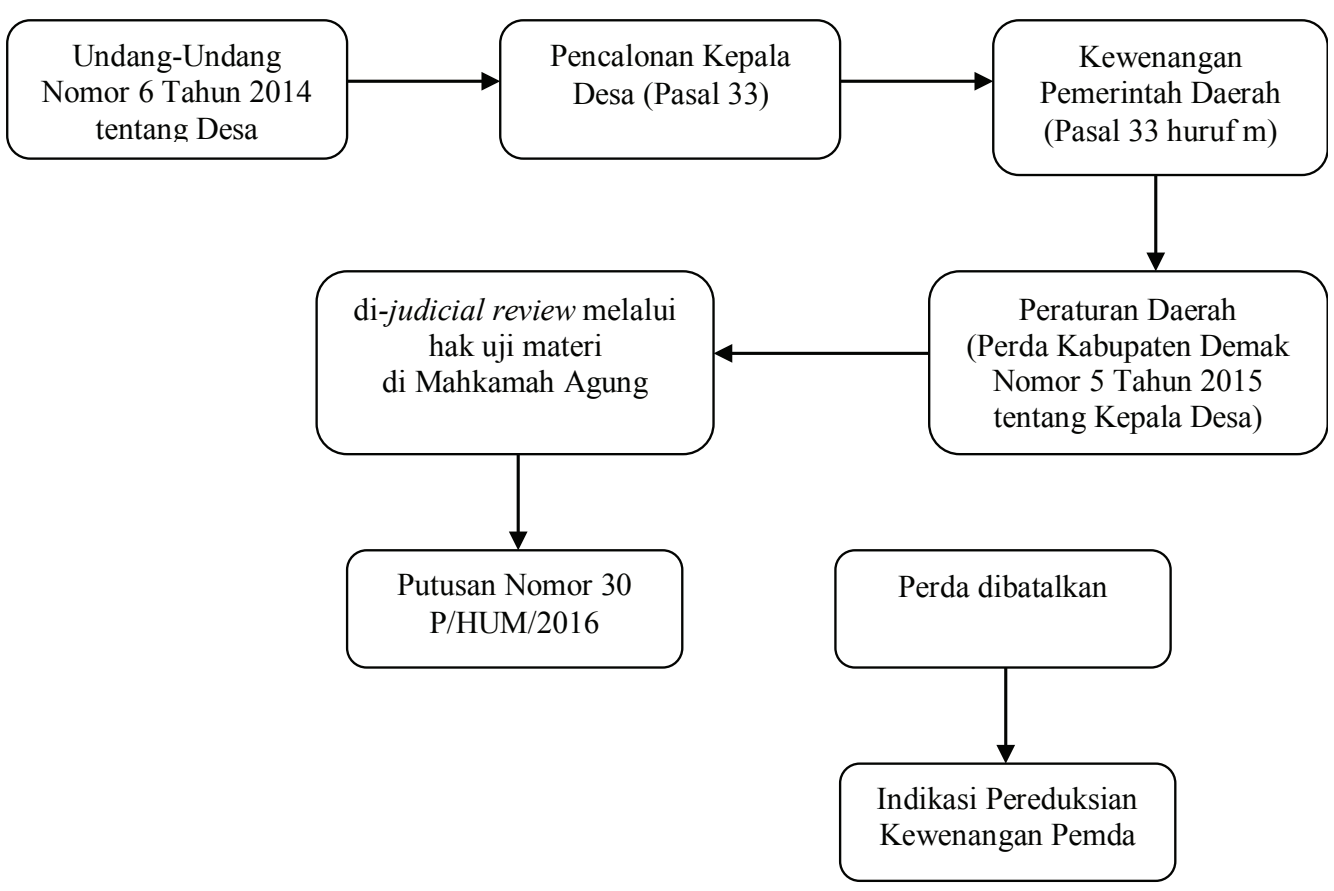

Gambar 1. Alur Berpikir 
Sistem administrasi di Indonesia saat ini memperlihatkan bahwa wilayah desa termasuk dalam bagian dari wilayah kecamatan, sehingga kecamatan menjadi instrumen koordinator dari penguasa supra desa (negara melalui pemerintah dan pemerintah daerah). Posisi desa di Indonesia saat ini justru kedudukannya semakin kokoh seiring dengan diberlakukannya Undang-Undang Desa. Pada Pasal 5 undang-undang a quo lebih lanjut menegaskan desa berkedudukan di kabupaten/kota.

Penjelasan undang-undang tersebut menyatakan bahwa desa dan desa adat mendapat perlakuan yang sama dari pemerintah dan pemerintah daerah. Pasal 371 ayat (1) UndangUndang Nomor 23 Tahun 2014 memperjelas bahwa pemerintahan daerah kabupaten/kota dapat dibentuk pemerintahan desa.

Penggunaan istilah "dibentuk" ini menegaskan bahwa pemerintah desa merupakan subsistem atau bagian dari pemerintah kabupaten/kota, karenanya ia menjalankan sebagian kewenangan pemerintah kabupaten/ kota. Dalam undang-undang ini, desa merupakan satuan pemerintah yang ada dalam pemerintah kabupaten/kota. Ini berbeda dengan istilah yang digunakan dalam Pasal 18 ayat (1) UUD NRI 1945 yang menyatakan: "Negara Kesatuan Republik Indonesia dibagi atas daerah-daerah provinsi dan daerah provinsi itu dibagi atas kabupaten dan kota ..."

Pemakaian istilah "dibagi atas daerahdaerah" memperlihatkan selain menghormati daerah otonom juga menegaskan adanya hubungan pemerintah pusat dan daerah bersifat hierarkis dan vertikal. Perbedaan model hubungan pusat dan daerah berdasarkan Pasal 18 UUD NRI 1945 dengan model hubungan kabupaten/ kota dengan desa berdasar Undang-Undang Nomor 23 Tahun 2014 tentang Pemerintahan Daerah. Namun hal tersebut berkembang dengan dikeluarkannya Undang-Undang Desa, bahwa pengakuan dan penghormatan atas desa yang sudah ada dengan keberagamannya sebelum dan sesudah terbentuknya Negara Kesatuan Republik Indonesia diakui dan diberikan kejelasan status dan kepastian hukum atas desa dalam sistem ketatanegaraan Republik Indonesia demi mewujudkan keadilan bagi seluruh rakyat Indonesia.

Implikasinya, desa secara politik bukan sekadar "bagian dari daerah," di mana sebelumnya hanya menerima "sisanya sisa" kewenangan dan keuangan daerah. Undang-undang tersebut meneguhkan kedudukan desa dalam sistem ketatanegaraan Negara Kesatuan Republik Indonesia di mana tiap-tiap desa dipimpin oleh kepala desa.

Kepala desa merupakan unsur terpenting yang harus ada dalam suatu sistem pemerintahan desa selain dari pada BPD. Kepala desa merupakan pimpinan tertinggi dalam suatu desa yang dipilih langsung oleh masyarakat desa.

Pemilihan kepala desa juga diatur dalam Pasal 33 Undang-Undang Desa bahwa persyaratan untuk dapat dicalonkan sebagai kepala desa sebagai berikut:

a. Warga negara Republik Indonesia.

b. Bertaqwa kepada Tuhan Yang Maha Esa.

c. Memegang teguh dan mengamalkan Pancasila, melaksanakan UUD NRI 1945, serta mempertahankan dan memelihara keutuhan Negara Kesatuan Republik Indonesia dan Bhinneka Tunggal Ika. 
d. Berpendidikan paling rendah tamat sekolah menengah pertama atau sederajat.

e. Berusia paling rendah 25 tahun pada saat mendaftar.

f. Bersedia dicalonkan menjadi kepala desa.

g. Terdaftar sebagai penduduk dan bertempat tinggal di desa setempat paling kurang satu tahun sebelum pendaftaran.

h. Tidak sedang menjalani hukuman pidana penjara.

i. Tidak pernah dijatuhi pidana penjara berdasarkan putusan pengadilan yang telah memperoleh kekuatan hukum tetap karena melakukan tindak pidana yang diancam dengan pidana penjara paling lama lima tahun atau lebih, kecuali lima tahun setelah selesai menjalani pidana penjara dan mengumumkan secara jujur dan terbuka kepada publik bahwa yang bersangkutan pernah dipidana serta bukan sebagai pelaku kejahatan berulang-ulang.

j. $\quad$ Tidak sedang dicabut hak pilihnya sesuai dengan putusan pengadilan yang telah mempunyai kekuatan hukum tetap.

k. Berbadan sehat.

1. Tidak pernah sebagai kepala desa selama tiga kali masa jabatan.

m. Syarat lain yang diatur dalam peraturan daerah (ditebalkan oleh penulis).

Kumpulan pasal di atas menjelaskan bahwa penyelenggaraan pemerintah desa dalam hal ini tugas dan kewajiban kepala desa diserahkan kepada masing-masing daerah. Sehingga dibutuhkan penyerahan wewenang dari pemerintah daerah kabupaten/kota ke pemerintah desa. Sudah tentu penyerahan urusan pemerintahan kabupaten tersebut menjadi urusan desa yang perlu dilakukan dengan cermat dan hati-hati, penyerahan urusan dimaksudkan untuk mendorong kemandirian dan keprakarsaan desa dan masyarakat sendiri, bukan dimaksudkan untuk melepas tanggung jawab pemerintah daerah kabupaten karena didasarkan atas sikap yang tidak bertanggung jawab ataupun disebabkan oleh ketidakmampuan pemerintah daerah menjalankan tugas dan kewajiban yang dibebankan padanya.

Pasal 66 Undang-Undang Desa juga menetapkan bahwa kepala desa memperoleh gaji dan penghasilan tetap setiap bulannya. Penghasilan tetap kepala desa bersumber dari dana perimbangan dalam APBN yang diterima oleh kabupaten/kota dan ditetapkan oleh APBD. Selain itu, kepala desa memperoleh jaminan kesehatan dan penerimaan yang lainnya yang sah.

Berdasarkan hal-hal tersebut sehingga wajar kiranya pemerintah daerah khususnya pemerintah kabupaten/kota mempunyai peran pula dalam mengatur pemilihan kepala desa termasuk dari alur pencalonannya. Hal ini sejalan pula dengan aturan hukum (Pasal 33 huruf $\mathrm{m}$ ) di mana pemerintah daerah berhak mengatur syarat lain yang ideal dalam pencalonan kepala desa melalui peraturan daerah berdasarkan kewenangan atribusi yang dimilikinya. Adapun atribusi adalah kewenangan pejabat yang langsung bersumber pada peraturan perundangundangan (Widodo, 2012: 427).

Persoalan yang timbul ketika Peraturan Daerah Kabupaten Demak Nomor 5 Tahun 2015 tentang Kepala Desa dibatalkan oleh Mahkamah Agung melalui proses judicial review dengan Putusan Nomor 30 P/HUM/2016. Konsep judicial review suatu peraturan daerah di Mahkamah Agung merupakan jalan yang bisa 
ditempuh setiap warga negara untuk mengawal produk hukum di suatu daerah tetap berada dalam koridor suatu tatanan hukum yang sesuai dengan UUD NRI 1945, termasuk dalam studi kasus yang diangkat dalam tulisan ini yaitu perkara pengujian Peraturan Daerah Kabupaten Demak Nomor 5 Tahun 2015 tentang Kepala Desa.

Duduk perkara Putusan Nomor $30 \mathrm{P} /$ HUM/2016 dimulai dari adanya permohonan keberatan hak uji materi terhadap Pasal 24 ayat (1) huruf o dan Pasal 106 ayat (2) Peraturan Daerah Kabupaten Demak Nomor 5 Tahun 2015 tentang Kepala Desa. Adapun bunyi pasal yang diuji tersebut yaitu:

Pasal 24:

(1) Yang dapat menjadi bakal calon kepala desa adalah penduduk desa setempat yang memenuhi syaratsyarat sebagai berikut:

o. Belum pernah menjabat sebagai kepala desa paling lama 18 tahun atau tiga kali masa jabatan.

Pasal 106:

(2) Kepala desa yang sudah pernah menjabat paling lama 18 tahun atau tiga kali masa jabatan tidak diperbolehkan untuk mencalonkan dan/atau dicalonkan kembali sebagai kepala desa.

Pasal-pasal tersebut dianggap bertentangan dengan Pasal 33 hurufl, Pasal 39 ayat (2) UndangUndang Nomor 6 Tahun 2014 dan Pasal 47 ayat (2) Peraturan Pemerintah Nomor 43 Tahun 2014. Pemohon menyatakan bahwa ketentuan waktu "18 tahun" di Pasal 24 ayat (1) huruf o dan Pasal 106 ayat (2) tidak mencerminkan kepastian hukum karena hal ini sebagaimana Pasal 47 ayat (5) Peraturan Pemerintah Nomor 43 Tahun 2014 bahwa masa jabatan kepala desa tidak dihitung dengan tahun melainkan dihitung menggunakan masa jabatan (periode). Dalam diktum putusannya, Mahkamah Agung mengabulkan permohonan pemohon yang pada pokoknya:

1. Menyatakan bahwa Pasal 24 ayat (1) huruf o dan Pasal 106 ayat (2) Peraturan Daerah Kabupaten Demak Nomor 5 Tahun 2015 yang mengatur syarat pencalonan kembali sebagai kepala desa dikaitkan dengan lamanya menjabat berdasarkan hitungan waktu, sedangkan Pasal 33 huruf 1 dan Pasal 39 ayat (2) Undang-Undang Nomor 6 Tahun 2014 dan Pasal 47 ayat (2) Peraturan Pemerintah Nomor 43 Tahun 2014 mengatur syarat pencalonan kembali dikaitkan dengan lamanya menjabat berdasarkan periodesasi;

2. Menyatakan bahwa pengaturan dalam objek permohonan merupakan norma baru yang berbeda dengan maksud dari norma yang telah diatur dalam peraturan perundang-undangan yang lebih tinggi, sehingga mempunyai konsekuensi hukum yang berbeda dari peraturan dasarnya tersebut;

3. Menyatakan bahwa materi muatan Pasal 24 ayat (1) huruf o dan Pasal 106 ayat (2) Peraturan Daerah Kabupaten Demak Nomor 5 Tahun 2015 tentang Kepala Desa terbukti bertentangan dengan peraturan perundang-undangan yang lebih tinggi yaitu Pasal 33 huruf 1 dan Pasal 39 ayat (2) Undang-Undang Nomor 6 Tahun 2014 tentang Desa dan Pasal 47 ayat (2) Peraturan Pemerintah Nomor 43 Tahun 2014 tentang Peraturan Pelaksanaan Undang-Undang Nomor 6 Tahun 2014 tentang Desa. 
Putusan hak uji materi tersebut yang pada akhirnya menyatakan perda a quo tidak mempunyai kekuatan hukum mengikat lagi dengan pertimbangan bahwa ketentuan Pasal 24 ayat (1) huruf o dan Pasal 106 ayat (2) Peraturan Daerah Kabupaten Demak Nomor 5 Tahun 2015 pada pokoknya mengatur syarat pencalonan kembali sebagai kepala desa dikaitkan dengan lamanya menjabat berdasarkan hitungan waktu dianggap oleh hakim yang memeriksa perkara tersebut merupakan bentuk penormaan baru yang berbeda dengan maksud dari norma yang telah diatur dalam peraturan perundang-undangan yang lebih tinggi, sehingga mempunyai konsekuensi hukum yang berbeda dari peraturan dasarnya tersebut.

Implikasinya ketentuan dalam perda a quo dinilai bertentangan dengan Pasal 33 huruf 1, Pasal 39 ayat (2) Undang-Undang Nomor 6 Tahun 2014 dan Pasal 47 ayat (2) Peraturan Pemerintah Nomor 43 Tahun 2014 mengatur syarat pencalonan kembali dikaitkan dengan lamanya menjabat berdasarkan periodesasi. Hal yang perlu diketahui bersama, peraturan perundangundangan yang dijadikan doelmatigheid dalam perkara hak uji materi ini tidak dibaca secara sistematis oleh hakim. Hakim mengabaikan Pasal 33 huruf $\mathrm{m}$ yang memberikan secara eksplisit kewenangan atribusi kepada daerah dalam pengaturan syarat pencalonan kepala desa.

Peraturan Daerah Kabupaten Demak Nomor 5 Tahun 2015 tentang Kepala Desa khususnya dalam Pasal 24 ayat (1) yang mengatur mengenai syarat seseorang dalam mencalonkan diri di pemilihan kepala desa perlu dianalisis dalam hal pemaknaan "periodesasi" dalam pencalonan kembali di pemilihan kepala desa dalam ketentuan pasal tersebut.

\section{Pemaknaan "Periodesasi" berdasarkan \\ Penafsiran Peraturan Perundang- Undangan}

Kebijakan pemerintah untuk memfasilitasi penyelenggaraan pemilihan kepala desa agar dapat berlangsung secara demokratis sebelum UndangUndang Nomor 23 Tahun 2014 yaitu dengan diterbitkannya Undang-Undang Nomor 32 Tahun 2004 tentang Pemerintah Daerah, ditindaklanjuti Peraturan Pemerintah Nomor 72 Tahun 2005 tentang Desa. Adapun di dalam peraturan tersebut, masa jabatan kepala desa adalah enam tahun terhitung sejak tanggal pelantikan. Bunyi eksplisit dari ketentuan tersebut yaitu:

Pasal 204 Undang-Undang Nomor 32 Tahun 2005 tentang Pemerintahan Daerah:

Masa jabatan kepala desa adalah enam tahun dan dapat dipilih kembali hanya untuk satu kali masa jabatan berikutnya.

Pasal 52 Peraturan Pemerintah Nomor 72 Tahun 2005 tentang Desa:

Masa jabatan kepala desa adalah enam tahun terhitung sejak tanggal pelantikan dan dapat dipilih kembali hanya untuk satu kali masa jabatan berikutnya.

Jika melihat konstruksi hukum tersebut, adanya Peraturan Daerah Kabupaten Demak Nomor 5 Tahun 2015 sebagai implikasi yuridis terbitnya Undang-Undang Nomor 6 Tahun 2014 tentang Desa, Peraturan Pemerintah Nomor 43 Tahun 2014 tentang Peraturan Pelaksanaan Undang-Undang Nomor 6 Tahun 2014 tentang Desa dan Peraturan Menteri Dalam Negeri Nomor 112 Tahun 2014 tentang Pemilihan Kepala Desa.

Menurut penulis, adanya norma di dalam perda a quo mengenai penambahan norma dengan menyebutkan secara eksplisit lamanya menjabat (18 tahun) dan periodesasi (3 periode) merupakan bentuk pengakomodiran keadaan 
hukum yang terjadi sebelum paket peraturan perundang-undangan mengenai kepala desa yang terbaru terbit. Adapun keadaan hukum yang dimaksud yaitu keadaan hukum saat berlakunya Pasal 204 Undang-Undang 32 Tahun 2004 tentang Pemerintahan Daerah dan Pasal 52 Peraturan Pemerintah Nomor 72 Tahun 2005 tentang Desa, di mana disebutkan bahwa masa jabatan kepala desa adalah enam tahun terhitung sejak tanggal pelantikan. Sehingga, dengan penafsiran sistematis ini tidak ada yang salah dengan penambahan frase 18 tahun karena secara mutatis mutandis hal itu dibenarkan karena satu periode jabatan kepala desa adalah enam tahun, sehingga tiga periode adalah 18 tahun. Dengan demikian tidak tepat kiranya Mahkamah Agung membatalkan peraturan daerah tersebut tanpa mempertimbangkan keadaan hukum yang berjalan sebelumnya.

Pada saat berlakunya Peraturan Daerah Kabupaten Demak Nomor 5 Tahun 2015 tentang Kepala Desa, Peraturan Daerah Kabupaten Demak Nomor 2 Tahun 2007 tentang Tata Cara Pencalonan, Pemilihan, Pengesahan, Pelantikan, Pemberhentian Sementara dan Pemberhentian Kepala Desa sebagaimana telah diubah dengan Peraturan Daerah Kabupaten Demak Nomor 2 Tahun 2014 tentang Perubahan atas Peraturan Daerah Kabupaten Demak Nomor 2 Tahun 2007 tentang Tata Cara Pencalonan, Pemilihan, Pengesahan, Pelantikan, Pemberhentian Sementara dan Pemberhentian Kepala Desa beserta peraturan pelaksanaannya, dicabut dan dinyatakan tidak berlaku. Tindakan yang tepat yang dilakukan pemerintah daerah Kabupaten Demak dengan mengakomodir keadaan hukum yang berdasar peraturan terdahulu walaupun secara eksplisit peraturan tersebut dinyatakan tidak berlaku kembali.

\section{Pemaknaan "Periodesasi" berdasarkan Keadaan Sosial}

Pemilihan kepala desa di Kabupaten Demak dilakukan secara langsung oleh penduduk desa dari calon yang memenuhi syarat. Kemudian calon kepala desa yang dipilih mendapat dukungan suara terbanyak ditetapkan menjadi kepala desa oleh panitia pemilihan dan disahkan oleh bupati. Adapun masa jabatan kepala desa adalah enam tahun, terhitung sejak tanggal pelantikan dan dapat diangkat kembali setelah melalui pemilihan untuk dua kali masa jabatan berikutnya (Gunawan, 2009: 2). Warga masyarakat dalam pemilihan kepala desa mempunyai hak pilih aktif maupun hak pilih pasif, yang ditetapkan sesuai dengan persyaratan yang diatur dalam undang-undang. Hak pilih aktif yaitu hak untuk memilih kepala desa, sedangkan hak pilih pasif merupakan hak seseorang untuk mencalonkan diri dalam pemilihan kepala desa (Gunawan, 2009: 2).

Perkembangan di Kabupaten Demak, pemilihan kepala desa pernah dilakukan di 151 desa dalam 14 kecamatan yang tersebar di Kabupaten Demak di mana pemilihan ini dilaksanakan serentak pada tanggal 28 Desember 2008 (Gunawan, 2009: 5). Berdasarkan keadaan faktual tersebut, tidak tepat kiranya pemohon merasa dirugikan atas dalih ketentuan penormaan 18 tahun di persyaratan pencalonan kepala desa. Hal ini karena tidak dapat dipungkiri penormaan tersebut sejalan dan sesuai dengan keadaan faktual di masyarakat Kabupaten Demak.

Hadjon, mengatakan bahwa setiap tindakan pemerintahan disyaratkan harus bertumpu atas kewenangan yang sah. Kewenangan itu diperoleh melalui tiga sumber, yaitu atribusi, delegasi, dan mandat. Kewenangan atribusilazimnya digariskan 
melalui pembagian kekuasaan negara oleh undang-undang dasar, sedangkan kewenangan delegasi dan mandat adalah kewenangan yang berasal dari pelimpahan (Hadjon, 2005: 78).

Atribusi terjadi ketika adanya pemberian wewenang pemerintahan yang baru oleh suatu ketentuan dalam peraturan perundang-undangan. Atribusi kewenangan dalam peraturan perundangundangan adalah pemberian kewenangan membentuk peraturan perundang-undangan yang pada puncaknya diberikan oleh UUD NRI 1945 atau undang-undang kepada suatu lembaga negara atau pemerintah. Kewenangan tersebut melekat terus-menerus dan dapat dilaksanakan atas prakarsa sendiri setiap diperlukan. Di sini dilahirkan atau diciptakan suatu wewenang baru yang disesuaikan dengan kondisi dari adresat kewenangan atribusi tersebut.

Penerbitan suatu peraturan sekalipun berdasarkan kewenangan atribusi harus mendasarkan kepada asas kemanfaatan, kebebasan menilai suatu, dan kebebasan memilih tindakan atau kebutuhan atau tujuan tertentu, serta harus pula bersesuaian dengan prinsip supremasi hukum. Sehingga dalam pembuatan peraturan harus pula memperhatikan dan mempertimbangkan asas legalitas hukum, yaitu peraturan yang dibuat harus secara materiil dan formal memenuhi ketentuan peraturan perundang-undangan, serta secara substansial tidak melanggar asas-asas kaidah hukum yang mendasar dan tidak bertentangan serta melampaui ataupun melebihi peraturan dasarnya (primary atribution) dan undang-undang sebagai "primary atribution" dari peraturan yang akan dibuat telah mendelegasikan dan atau mensubdelegasikan kewenangan tersebut kepada pembuat peraturan yang lebih rendah.
Penulis menilai bahwa Peraturan Daerah Kabupaten Demak Nomor 5 tahun 2015 telah memenuhi hal-hal tersebut. Pun demikian, pemerintah daerah mempunyai kewenangan yang sah untuk menambah syarat yang diperlukan dalam pencalonan kepala desa. Terlebih penambahan syarat tersebut sebenarnya secara implisit "hanya" untuk menjabarkan secara detail mengenai jangka waktu maksimal pencalonan kembali kepada pemilik hak untuk dipilih dalam pemilihan kepala desa. Di sisi lain peraturan daerah adalah peraturan hukum yang dibuat oleh pemerintah daerah bersama dengan DPRD untuk melaksanakan tugas pemerintahan di daerah, pun demikian termasuk dalam proses penyelenggaraan pemerintahan di daerah yang muncul melalui kewenangan atribusi.

Peraturan daerah merupakan produk hukum yang bersifat mengatur (regeling) yang artinya peraturan daerah merupakan produk hukum yang dalam pembuatannya membutuhkan persetujuan masyarakat yang dalam hal ini diwakilkan oleh DPRD sebagai perwakilan masyarakat di daerah (Sukirno, 2013: 140). Keberadaan perda dalam penyelenggaraan pemerintahan daerah tidak lepas dari prinsip desentralisasi yang dilakukan oleh Pemerintah Pusat. Disamping terdapat dalam UUD 1945 Pasal 18 Ayat (6) kewenangan pembuatan Perda juga terdapat dalam UndangUndang Nomor 32 Tahun 2004 tentang Pemerintahan Daerah dan Undang-Undang Nomor 12 Tahun 2011 tentang Pembentukan Peraturan perundang-undangan.

Jika ditilik secara komprehensif, hak uji materi yang telah dilakukan oleh hakim agung terkait perda tersebut dan dibenturkan dengan konsep perolehan kewenangan atribusi jelasjelas telah memperlihatkan pertimbangan yang dilakukan lebih kepada pertimbangan 
sederhana yang hanya menitikberatkan pada penormaan di peraturan yang lebih tinggi tanpa mempertimbangkan penafsiran sistematis peraturan perundang-undangan, keadaan sosial yang terjadi di daerah yang bersangkutan dan kewenangan yang dimiliki pemerintah daerah. Padahal dalam hal ini, di Undang-Undang Desa secara eksplisit memberikan kewenangan atribusi kepada pemerintah daerah untuk mengatur syarat tambahan perihal pencalonan kepala desa jika diperlukan.

Putusan Nomor 30 P/HUM/2016 telah secara nyata mereduksi kewenangan Pemerintah Daerah Kabupaten Demak dalam rangka pemilihan kepala desa khususnya perihal syarat pencalonan kepala desa. Pereduksian tersebut tentu saja mencederai konsep otonomi daerah yang memberikan keleluasaan pemerintah daerah untuk mandiri termasuk dalam hal pemerintahannya.

\section{KESIMPULAN}

Putusan Nomor $30 \mathrm{P} / \mathrm{HUM} / 2016$ yang bermuara pada pembatalan Peraturan Daerah Kabupaten Demak Nomor 5 Tahun 2015 memiliki dampak hukum terhadap kewenangan atribusi Pemerintah Daerah Kabupaten Demak berdasarkan Undang-Undang Nomor 6 Tahun 2014 tentang Desa. Dampak yang dimaksud yaitu pereduksian kewenangan atribusi pemerintah daerah dalam hal pencalonan pemilihan kepala desa. Hak uji materi yang dilakukan oleh Mahkamah Agung tanpa melalui pertimbangan hal-hal yang menjadi fundamental lain yang menjadi dasar terbentuknya suatu perda. Kewenangan atribusi yang dimiliki pemerintah daerah (dalam hal ini Pemerintah Daerah Kabupaten Demak) seolah-olah diabaikan oleh hakim yang melakukan uji materi perda a quo. Padahal pembentuk undang-undang melalui Undang-Undang Nomor 6 Tahun 2014 tentang Desa telah memberikan kewenangan atribusi tersebut secara eksplisit dalam Pasal 33 huruf m.

\section{SARAN}

Putusan hak uji materi merupakan putusan yang penting karena berkaitan dengan peraturan yang diuji bersifat regeling dan berlaku untuk banyak pihak. Sehingga penting kiranya para hakim hati-hati dalam membuat pertimbangan yang nantinya bermuara pada putusan yang dihasilkan. Hendaknya hakim tidak hanya secara sempit melihat suatu peraturan bertentangan dengan peraturan yang lebih tinggi atau tidak, tetapi juga mempertimbangkan hal-hal lain yang berkaitan dengan terbentuknya peraturan tersebut demi memperoleh putusan uji materi yang ideal.

\section{DAFTAR ACUAN}

Asshiddiqqie, J. (2006). Perihal undang-undang. Jakarta: Konstitusi Press.

Atmosudirjo, P. (2006). Hukum administrasi negara. Jakarta: Ghalia Indonesia.

Ayunita, K. (2014, Desember). Analisis yuridis terhadap pembatalan peraturan daerah. Jurnal Jurisprudentie, 1(2), 37-52.

Brouwer \& Schilder. (1998). A survey of Dutch Administrative Law. Nijmegen: Ars Aeguilibri.

Febriansyah, F. I. (2016, Desember). Konsep pembentukan peraturan perundang-undangan di Indonesia. Jurnal Perspektif, 21(3), 220-229.

Ghozali, D. A. (2015). Penggerak prakarsa 
masyarakat desa. Jakarta: Kementerian Desa, Pembangunan Daerah Tertinggal dan Transmigrasi Republik Indonesia.

Gunawan, T. (2009). Pelaksanaan pemilihan kepala desa di Desa Sri Wulan Kecamatan Sayung Kabupaten Demak Masa Jabatan Periode 2009. 2015. Skripsi. Semarang: FISIP UNESA.

Hadjon, P. M. (2005). Pengantar hukum administrasi Indonesia. Yogyakarta: Gadjah Mada University Press.

Hakim, L. (2011, Juni). Kewenangan organ negara dalam penyelenggaraan pemerintahan. Jurnal Konstitusi, 4(1), 103-130.

Hariyati, E. (2015, Agustus). Peran kepala desa dalam penyelenggaraan Pemerintahan Desa Batu Balai Kecamatan Muara Bengkal Kabupaten Kutai Timur. Jurnal Ilmu Pemerintahan, 3(4), 1914-1927.

Hidjaz, K. (2010). Efektivitas penyelenggaraan kewenangan dalam sistem pemerintahan daerah di Indonesia. Makassar: Pustaka Refleksi.

Huda, N. (2008, Januari). Urgensi judicial review di Indonesia. Jurnal Hukum, 1(15), 101-120.

(2017). Urgensi Pengaturan Desa dalam Undang-Undang Dasar negara Republik Indonesia Tahun 1945. Padjajaran Jurnal Ilmu Hukum, 4 (1), hlm. 1 - 18.

Hutagalung, D. (2005, Oktober). Menapaki jejakjejak pemikiran Soepomo mengenai negara Indonesia. Jurnal Hukum Jentera, 3(10), 1-18.

Janwandri. (2013, Maret). Proses pemilihan kepala desa. Jurnal Ilmu Pemerintahan, 1(1), 235247.

Mahfud, M.D. (2003). Demokrasi \& konstitusi di Indonesia. Jakarta: Rineka Cipta.
Maryadi, F. (2010, Juni). Nilai-nilai filosofis Putusan Mahkamah Konstitusi yang final \& mengikat. Jurnal Konstitusi, 7(3), 83-103.

Marzuki, P. M. (2007). Penelitian hukum. Jakarta: Prenada Media Group.

Nasihuddin, A. A. (2013, September). Implementasi hak uji materiil peraturan daerah kabupaten/ kota oleh Mahkamah Agung \& pengaruhnya terhadap pemberdayaan daerah. Jurnal Dinamika Hukum, 13(3), 428-439.

Ridwan, H. R. (2013). Hukum administrasi negara. Jakarta: Raja Grafindo Persada.

Rikardo, R. (2016) Pelaksanaan Pemilihan Kepala Desa di Desa Sikijang Kecamatan Logas Tanah Darat Kabupaten Singingi Menurut UU Nomor 6 Tahun 2014. Skripsi, Universitas Islam Negeri Sultan Syarif Kasim Riau.

Saiful. (2014, Desember). Eksistensi peraturan desa pasca berlakunya Undang-Undang Nomor 12 Tahun 2011. Jurnal Ilmu Hukum Legal Opinion, 6(2), 1-9.

Stout, H. D. (2004). De betekenissen van de wet. Zwolle: W.E.J. Tjeenk Willink, Zwolle.

Sukirno, D. (2013). Hukum, konstitusi \& konsep otonomi. Malang: Setara Press.

Taufiq, M. (2011). Hukum pemerintahan daerah di Indonesaia. Jakarta: Rineka Cipta.

Widodo, H. (2012, Desember). Politik hukum hak interpelasi Dewan Perwakilan Rakyat Republik Indonesia. Jurnal Rechtsvinding, 1(3), 419436.

Zamroni, M. (2013, September). Pengujian peraturan daerah: Sebuah telaahan kritis (Testing local regulations: A critical findings). Jurnal Legislasi Indonesia, 10(3), 259-269. 